SAŠA ZELJKOVIĆ' ${ }^{*}$, JELENA PENAVIN ŠKUNDRIĆ', DIJANA JELIĆ', SLAVICA SLADOJEVIĆ ${ }^{3}$ LJUBICA VASILJEVIĆ 4

${ }^{1}$ University of Banja Luka, Faculty of Science and Mathematics, Banja Luka, Bosnia and Herzegovina. ${ }^{2}$ University of Banja Luka, Medical Faculty - Pharmacy department, Banja Luka, Bosnia and Herzegovina, ${ }^{3}$ University of Banja Luka, Faculty of Technology, Banja Luka, Bosnia and Herzegovina, "University of East Sarajevo, Faculty of Technology Zvornik, Zvonik, Bosnia and Herzegovina
Scientific paper

UDC:628.316.13

doi:10.5937/ZasMat1503340Z

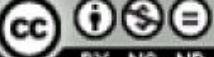

Zastita Materijala 56 (3)

$340-344$ (2015)

\title{
Interaction of hexavalent chromium and BSCF perovskite in water solutions
}

\begin{abstract}
In this study, interaction of BSCF perovskite and hexavalent chromium in the aqueous solution was followed to provide additional useful insight in chemistry and behavior of this material.

Adsorption experiments were carried out systematically by batch experiments to investigate the influence of contact time, temperature and initial concentration of metal ions. The adsorption data obtained were described by the Freundlich and Langmuir adsorption isotherm model.

Thermodynamic study of hexavalent chromium adsorption on BSCF perovskite showed that the spontaneous adsorption process will be favored at higher temperatures (from $343 \mathrm{~K}$ ) depending on the chromium concentration in water.
\end{abstract}

Keywords: BSCF, perovskite, adsorption, chromium.

\section{INTRODUCTION}

Recently, great attention is given to investigations of intermediate temperature solid oxide fuel cells (IT-SOFCs). An integral part of the IT-SOFCs are interconnects made of metal alloys - steels with chromium contents over $20 \mathrm{wt} \%[1,2]$. IT-SOFCs cathode material must be highly tolerant toward the deposition and poisoning of $\mathrm{Cr}$ species in order to achieve the long-term stability of the electrodes $[3,4]$. The $\mathrm{Cr}$ poisoning of the perovskite cathode material and subsequent degradation of the whole system occur as a consequence of the reaction of $\mathrm{Cr}_{2} \mathrm{O}_{3}$ with oxygen and water to form various gaseous hexavalent $\mathrm{Cr}$ species under the ITSOFCs working temperatures $[5,6]$.

In recent years, it was found that $\mathrm{Ba}_{0.5} \mathrm{Sr}_{0.5} \mathrm{Co}_{0.8} \mathrm{Fe}_{0.2} \mathrm{O}_{3-\delta}$, as a common material for oxygen membranes and IT - SOFCs, is not

\footnotetext{
${ }^{*}$ Corresponding author: Sasa Zeljković

E-mail: sasa.zeljkovic@unibl.rs

Paper received: 22. 04. 2015.

Paper accepted: 17. 06. 2015.

Paper is available on the website: www.idk.org.rs/casopis
}

chromium-tolerant [7]. Performed study resulted in clear evidences of the chromium deposition and poisoning. The reactivity of the BSCF material toward copper and cobalt ions in the water environment was previously studied [8]. Copper and cobalt ions were adsorbed at the BSCF surface.

In this paper, we investigated the hexavalent chromium adsorption and deposition from the water solutions in order to determine and better understand reactivity of this chemical specie with BSCF perovskite. The adsorption has been described by the Freundlich and Langmuir adsorption isotherms as a mathematical calculation model.

\section{EXPERIMENTAL}

BSCF $\left(\mathrm{Ba}_{0.5} \mathrm{Sr}_{0.5} \mathrm{Co}_{0.8} \mathrm{Fe}_{0.2} \mathrm{O}_{3-\delta}\right)$ powder (Praxair) was annealed in air at $1273 \mathrm{~K}$ for $6 \mathrm{~h}$. X-ray diffraction (XRD) was performed on a Philips SIEMENS D5000 instrument using $\mathrm{Cu}-\mathrm{K} \alpha$ x-ray tube $(\lambda=154 \mathrm{~nm})$ and $\Theta-2 \Theta$ configuration. Data were collected in a continuous-scan mode in the range of $20^{\circ}$ to $100^{\circ}$ with intervals of $0.02^{\circ}$, confirming the presence of single phase BSCF, Figure 1. 


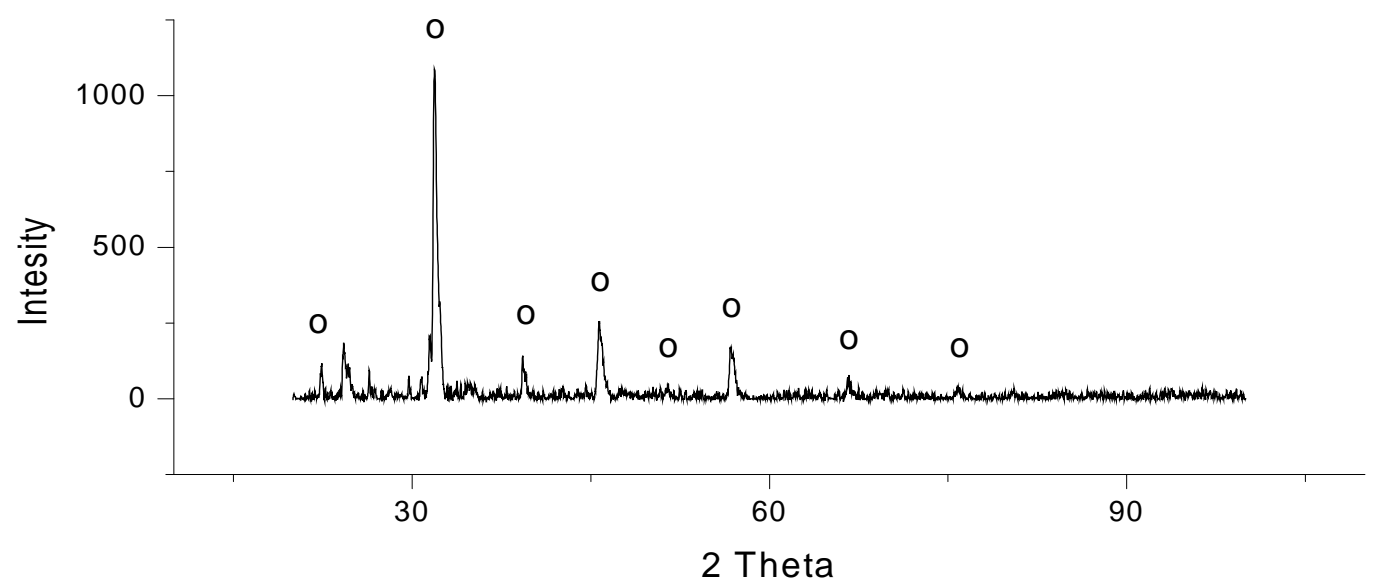

Figure 1 - XRD analysis with marked peaks of $\mathrm{Ba}_{0.5} \mathrm{Sr}_{0.5} \mathrm{Co}_{0.8} \mathrm{Fe}_{0.2} \mathrm{O}_{3-\delta}(0)$ perovskite.

The specific surface of $\mathrm{Ba}_{0.5} \mathrm{Sr}_{0.5} \mathrm{Co}_{0.8} \mathrm{Fe}_{0.2} \mathrm{O}_{3-\delta}$ perovskite determined by the Brunauer-EmmettTeller (BET) method after four hours of annealing at $673 \mathrm{~K}$ was close to $2 \mathrm{~m}^{2} \mathrm{~g}^{-1}$. The approximate $\mathrm{pH}$ of the BSCF perovskite samples $\left(0.1 \mathrm{gcm}^{-3}\right.$ water suspension) has been determined by universal paper indicator and it was about $\mathrm{pH}$ 5.5.

The aqueous solutions containing chromium of known concentration $(0.01,0.02,0.03,0.04,0.05$ moldm $^{-3}$ ) were mixed with a given mass of adsorbent for a given period of time. Chromium solutions were prepared by dissolving of $\mathrm{K}_{2} \mathrm{Cr}_{2} \mathrm{O}_{7}$ salt (p.a. purity, Lachner).

In each experiment mass of $0.3 \mathrm{~g}$ of adsorbate (BSCF) was mixed with $0.03 \mathrm{dm}^{-3}$ of chromium aqueous solution. The suspensions were mixed and left thermostating in a glass container at four different temperatures $(273,293,303$ and $313 \mathrm{~K})$ in the duration of 1 hour. After the adsorption the solution was separated from adsorbent by filtering through the blue band filter paper. The amount of solute adsorbed by the adsorbent is summed to be the difference between the initial concentration (before contact with the adsorbent) and the solute concentration after the contact period.

The chromium concentration was determined by the AAS - atomic absorption spectroscopy (Thermo Electron Corporation S2 AA System).

\section{RESULTS AND DISSCUSION}

The batch experiments were designed to investigate the influence of contact time, temperature and initial concentration of metal ions. Prepared chromium water solutions were slightly acidic ( $\mathrm{pH} \mathrm{5).} \mathrm{With} \mathrm{this} \mathrm{level} \mathrm{of} \mathrm{acidity} \mathrm{and} \mathrm{with}$ regard to concentration of $\mathrm{Cr}(\mathrm{VI})$ it can be assumed that in all used solutions chromium was in anionic $\mathrm{Cr}_{2} \mathrm{O}_{7}{ }^{2-}$ form $[9,10]$. Figure 2 Influence of $\mathrm{pH}$ on the sorption was not further studied.
The amount of adsorbed chromium also depends on the contact time. The optimal time for complete sorption was specified at the temperature of $313 \mathrm{~K}$ in the time interval of 180 minutes, where it was determined that the optimal time for sorption is 60 minutes after which there has been no increase in adsorption. (Figure 3) The initial rapid adsorption rate may be due to the availability of positively charged active sites. Subsequent slow adsorption speaks in favor of electrostatic repulsion between negatively charged, previously adsorbed, adsorbate and anionic species present in the solution.

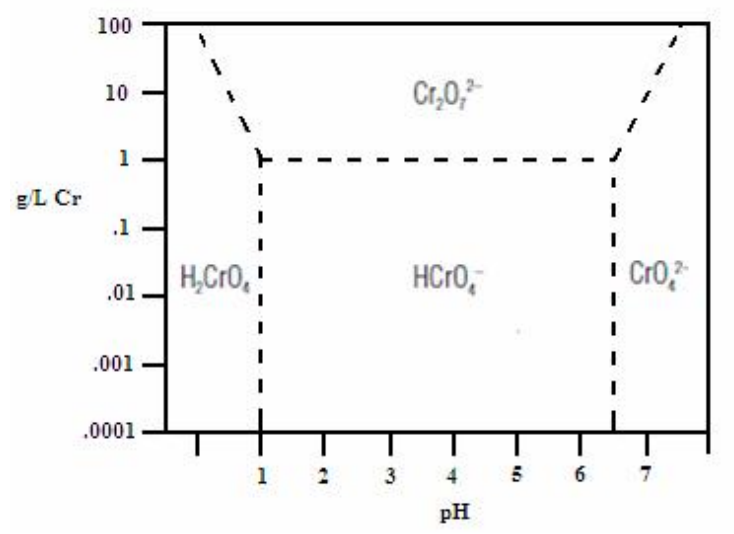

Figure 2 - Relative distribution of $\mathrm{Cr}(\mathrm{VI})$ species in water as a function of $\mathrm{pH}$ and $\mathrm{Cr}(\mathrm{VI})$ concentration.

The sorption of chromium onto BSCF increased with increasing temperature. The increase in the sorption efficiency indicates an endothermic process. At $273 \mathrm{~K}$ the sorption capacity is reached and stable at $20 \mathrm{mg} \mathrm{g}^{-1}$, regardless of chromium concentration. At 293, 303 and $313 \mathrm{~K}$ the maximum sorption capacity does not seem to be reached as visible from the slope of the related curves. The maximum adsorption capacity was $80 \mathrm{mg} \mathrm{g}^{-1}$ at $313 \mathrm{~K}$, Figure 4 . 


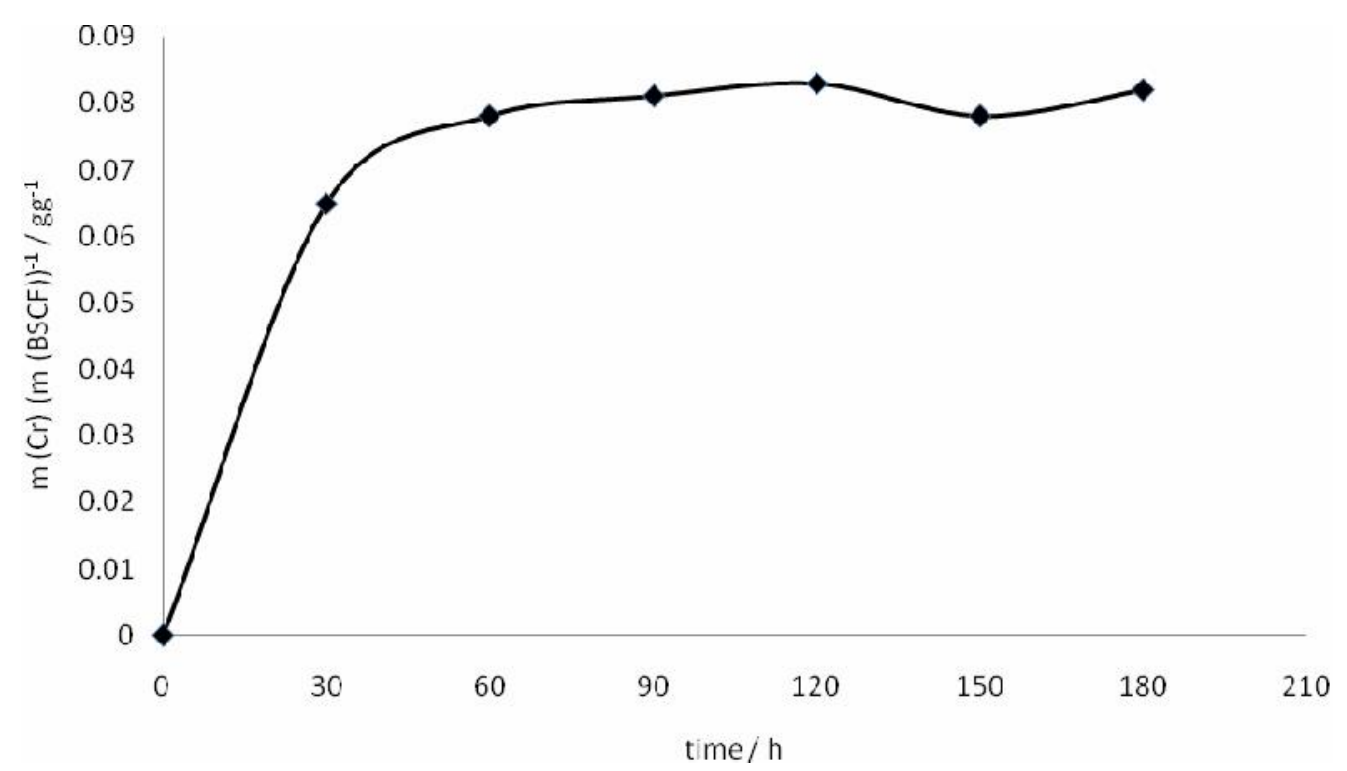

Figure 3 - Effect of contact time on removal of $\mathrm{Cr}(\mathrm{VI})$ for the Cr-BSCF system (recorded at $313 \mathrm{~K}$ in the time interval of 180 minutes).

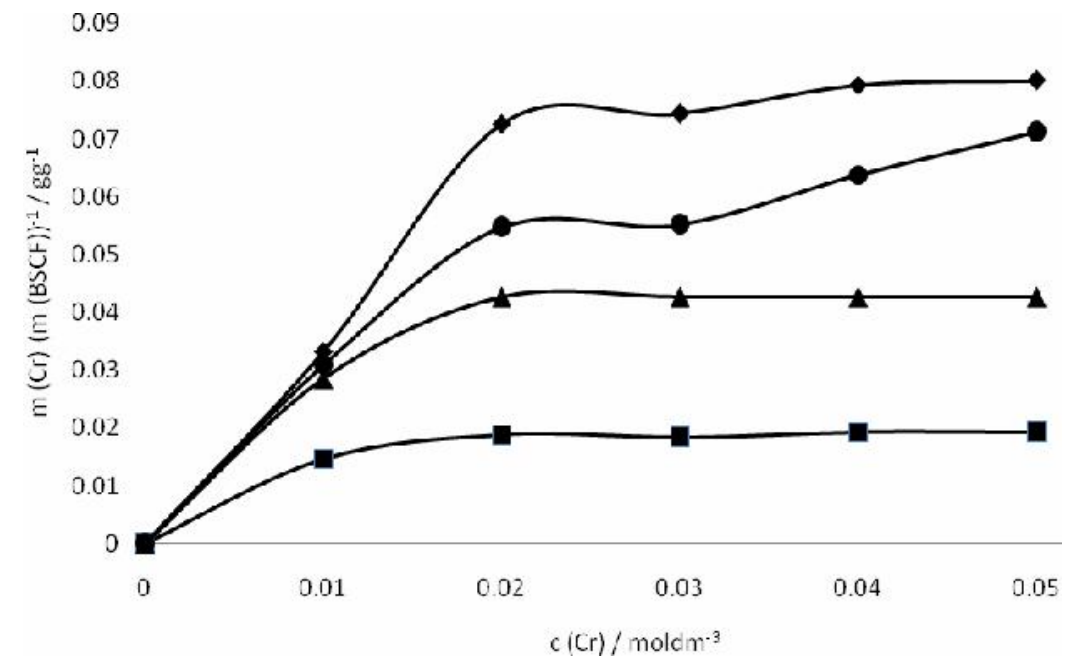

Figure 4 - Adsorption isotherms for the Cr-BSCF system recorded at 273（ ), 293（ ), 303 and $313 K(\diamond)$.

Chroimum sorption most probably included interaction of negativly charged oxygen, in dichromate anionic molecules, and active sites at the surface of BSCF perovskite. Active sites are most probably present at the place of stoichiometricaly defficient oxygen. Oxygen nonstoichiometry (as one of the BSCF characteristics) is previously explained by many authors [11-14] and proven to be highly temperature dependent. The increased presence of oxygen defects with increasing temperature could explain the growing BSCF affinity toward chromium.

The obtained results of $\mathrm{Cr}(\mathrm{VI})$ adsorption BSCF perovskite at 273, 293, 303 and $313 \mathrm{~K}$, were also analyzed using Langmuir adsorption model. The results are shown in Table $1 \mathrm{a}$ and $1 \mathrm{~b}$. Obtained positive enthalpy and entropy values indicate that the process of adsorption of $\mathrm{Cr}(\mathrm{VI})$ on $\mathrm{BSCF}$ is favored at higher temperatures. 
Table 1 - (a and b) Overview of experimental data obtained from the Langmuir adsorption isotherm and thermodynamic functions calculated for the adsorption process of $\mathrm{Cr}(\mathrm{VI})$ on BSCF perovskite

a)

\begin{tabular}{|c|c|c|c|c|}
\hline Temperature & $\begin{array}{c}\mathrm{R} \text { - Linear Correlation } \\
\text { Coefficient }\end{array}$ & $\begin{array}{c}\mathrm{q}_{\mathrm{m}} \text { (adsorption } \\
\text { capacity) }\end{array}$ & $\begin{array}{c}\mathrm{K}_{\mathrm{L}} \text { (Langmuir's } \\
\text { constant) }\end{array}$ & $\begin{array}{c}\mathrm{R}_{\mathrm{L}}(0<\mathrm{R}<1) \\
\text { favorable }\end{array}$ \\
\hline $273 \mathrm{~K}$ & 0.99896 & 0.000389 & 436.85 & 0.184 for $0.0101 \mathrm{M}$ \\
\hline $293 \mathrm{~K}$ & 0.99867 & 0.000856 & 678.80 & 0.127 for $0.0101 \mathrm{M}$ \\
\hline $303 \mathrm{~K}$ & 0.98879 & 0.00155 & 152.81 & 0.393 for $0.0101 \mathrm{M}$ \\
\hline $313 \mathrm{~K}$ & 0.94659 & 0.0017 & 181.17 & 0.353 for $0.0101 \mathrm{M}$ \\
\hline
\end{tabular}

b)

\begin{tabular}{|c|c|c|c|c|c|c|}
\hline \multirow[t]{2}{*}{$\begin{array}{c}\mathrm{c} \\
\mathrm{mol} / \mathrm{L}\end{array}$} & & $\Delta S^{0}$ & & $\Delta G^{0} \quad(423$ & $\mathrm{T}_{\text {spontaneously }}$ & $\begin{array}{c}\text { R - Linear Correlation } \\
\text { Coefficient }\end{array}$ \\
\hline & $\mathrm{J} / \mathrm{mol}$ & $\mathrm{J} / \mathrm{molK}$ & $\mathrm{J} / \mathrm{mol}$ & K) J/mol & & \\
\hline 0.0101 & 26852.5 & 72.047 & 5382.5 & -3622.5 & 372.7 & 0.97207 \\
\hline 0.0192 & 41225.3 & 119.206 & 5702.1 & -9198.7 & 345.83 & 0.99397 \\
\hline 0.0308 & 33141.5 & 85.104 & 7781.5 & -2857.8 & 389.42 & 0.99812 \\
\hline 0.0403 & 32237.2 & 79.727 & 8519.3 & -1486.8 & 404.34 & 0.99991 \\
\hline 0.0515 & 31573.1 & 75.238 & 9153.5 & -252.1 & 419.55 & 0.99204 \\
\hline
\end{tabular}

The free Gibbs energies are positive up to $T$ (spontaneously), after which $G^{\circ}$ is negative which confirmes spontaneous process. A positive enthalpy value goes in favor of an endothermic process, and increases with increasing temperature. The positive value of entropy represents an increase in the degree of disorder in the system with an increasing adsorption, ie, that there is a higher degree of freedom of the molecules in the liquid-solid boundary during the adsorption process.

\section{CONCLUSION}

$\mathrm{Ba}_{0.5} \mathrm{Sr}_{0.5} \mathrm{Co}_{0.8} \mathrm{Fe}_{0.2} \mathrm{O}_{3-\delta}, \quad$ (BSCF) perovskite oxide interaction with hexavalent chromium was investigated in the water environment. The influences of contact time, temperature and initial concentration of metal ions were evaluated and in final form described with Freundlich adsorption model.

Sorption of hexavalent chromium was endothermic that could indicate chemisorption.

It was found that the affinity of BSCF toward chromium increases with increasing temperature and metal ions concentration. Such behavior could be ascribed to the chemical structure of BSCF perovskite, its active sites on the place of deficient oxygen and the bonds that could form with the sorbent.

Although in this study the reactivity of chromium was followed at low temperatures and in an aqueous environment, the present results provide further insight into the chemistry of the reaction process. Recorded affinity of the BSCF perovskite to chromium at low temperatures speaks in favor of thinking that BSCF is not chromium-depositiontolerant material, regardless of temperature. That could lead to possible conclusion that the reduction in the SOFC operational temperature would not prevent the chromium deposition and poisoning effect

\section{REFERENCES}

[1] W. Z. Zhu, S. C. Deevi (2003) Opportunity of metallic interconnects for solid oxide fuel cells: a status on contact resistance, Mater.Res. Bull., 38, 957 - 972.

[2] J. W.Fergus (2005) Metallic interconnects for solid oxide fuel cells, Mater. Sci. Eng., 397, 271 - 283.

[3] J. W.Fergus (2007) Effect of cathode and electrolyte transport properties on chromium poisoning in solid oxide fuel cells, Int. J. Hydrog. Energy, 32, 3664 3671. 
[4] S.P. Jiang, Y. D.Zhen (2008) Mechanism of $\mathrm{Cr}$ deposition and its application in the development of $\mathrm{Cr}$ - tolerant cathode of solid oxide fuel cells, Solid State Ionics, 179, 1459 - 1464.

[5] K.Hilpert., D.Das, M.Miller, D.H.Peck, R.Weiss (1996) Chromium vapor species over solid oxide fuel cells interconnect materials and their potential for degradation processes, J. Electrochem. Soc., 143, 3642 - 3647.

[6] M.Stanislowski, E.Wessel, K.Hilpert, T.Markus, L.Singheiser (2007) Chromium vaporization from high-temperature alloys I. Chromia-forming steels and the influence of outer oxide layers, J. Electrochem. Soc., 154, 295 - 306.

[7] Y. M.Kim, X. B.Chen, S.P. Jiang, J.Bae (2011) Chromium Deposition and Poisoning at $\mathrm{Ba}_{0.5} \mathrm{Sr}_{0.5} \mathrm{Co}_{0.8} \mathrm{Fe}_{0.2} \mathrm{O}_{3-\delta}$ Cathode of Solid Oxide Fue Cells, Electrochem. Solid State Lett., 14, 41 - 45.

[8] S.Zeljković, D.Jelić, Z.Levi, J.Penavin-Škundrić, D.Vranković, S.Vujnić (2013) Proceedings of the conference - Contemporary materials, Banja Luka, p. 129-137.
[9] C.D.Palmer, R.W.Puls (1994) Natural Attenuation of Hexavalent Chromium in Groundwater and Soils, U.S. EPA, Washington,1-12.

[10] F.Granados-Correa, J.Jiménez (2009) Chromium (VI) adsorption on boehmite, J. Hazard. Mater., 162(2 - 3) 1178 - 84

[11] S.Zeljković, T.Ivas, S.Vaucher, L. J.Gauckler (2014) The changes of $\mathrm{Ba}_{0.5} \mathrm{Sr}_{0.5} \mathrm{Co}_{0.8} \mathrm{Fe}_{0.2} \mathrm{O}_{3-\delta}$ perovskite oxide on heating in oxygen and carbon dioxide atmospheres, J. Serb. Chem. Soc., 79(9) 1141 1154.

[12] S.Mclntosh, J. F.Vente, W. G.Haije, D.H.A.Blank, H.J.M.Bouwmeester (2006) Structure and oxygen stoichiometry of $\mathrm{SrCo}_{0.8} \mathrm{Fe}_{0.2} \mathrm{O}_{3-} \quad \delta$ and $\mathrm{Ba}_{0.5} \mathrm{Sr}_{0.5} \mathrm{Co}_{0.8} \mathrm{Fe}_{0.2} \mathrm{O}_{3-\delta}$, Solid State lonics, 177 , 1737 - 1742.

[13] P.Zeng, Z.Chen, W.Zhou, H.Gu, Z.Shao, S.Liu (2007) Re-evaluation of $\mathrm{Ba}_{0.5} \mathrm{Sr}_{0.5} \mathrm{Co}_{0.8} \mathrm{Fe}_{0.2} \mathrm{O}_{3-\delta}$ perovskite as oxygen semi - permeable membrane J. Membr. Sci., 291,148 - 156.

[14] E.Bucher, A.Egger, P.Ried, W.Sitte, P.Holtappels (2008) Oxigen nonstoichiometry and exchange kinetics of $\mathrm{Ba}_{0.5} \mathrm{Sr}_{0.5} \mathrm{Co}_{0.8} \mathrm{Fe}_{0.2} \mathrm{O}_{3-\delta}$, Solid State lonics, 179, 1032 - 1035.

\section{IZVOD}

\section{INTERAKCIJA HEKSAVALENTNOG HROMA I BSCF PEROVSKITA U VODENOJ SREDINI}

U ovoj studiji je praćena interakcija BSCF perovskita i heksavalentnog hroma u vodenoj sredini kako bi se obezbijedile korisne informacije o hemizmu i ponašanju ovog materijala.

Eksperimenti adsorpcije su izvedeni sistematično i u serijama kako bi se ispitali uticaji dužine kontakta, temperature $i$ inicijalne koncentracije metalnih jona. Podaci su opisani Freundlichovim i Langmuirovim adsorpcionim modelom.

Termodinamička studija adsorpcije heksavalentnog hroma na BSCF perovskitu pokazala je da je spontani proces adsorpcije favorizovan pri višim temperaturama (od 343K) zavisno od koncentracije hroma u vodenoj sredini.

Ključne riječi: $B S C F$, perovskit, adsorpcija, hrom.

Naučni rad

Rad primljen: 22. 04. 2015.

Rad prihvacen 17. 06. 2015

Rad je dostupan na sajtu: www.idk.org.rs/casopis 